\title{
The Influence of Biochar and Substrates Application on the Parameters and Yield of Mini-Tubers of the Charoit Potato Variety
}

\author{
Alexander Rodionenko ${ }^{1}$, Dmitry Danilov ${ }^{1,2^{*}}$ and Tamara Shelabina ${ }^{1}$ \\ ${ }^{1}$ Russian Potato Research Center, Leningrad Scientific Research Institute of Agriculture BELOGORKA, 1, Institutskaya Street, \\ Belogorka, Leningrad Region, 188338, Russia \\ ${ }^{2}$ Saint-Petersburg State Forest Technical University named after SM Kirov, 5, Institutsky Lane, Saint-Petersburg, 194021, Russia
}

\begin{abstract}
The objects of research were potato meristem plants of the Charoite variety, mass and the number of mini-tubers grown on the "Agrobalt S" peat fertilizer and in a mixture of "ORVI" and biochar substrate in a closed greenhouse. A statistically significant effect of the use of this substrate and biochar on the increase in the number of standard mini-tubers relative to the control variant using only peat soil was established. The yield of standard tubers $(9-60 \mathrm{~mm})$ was $78 \%$ when using "Agrobalt S" peat soil; $10 \%$ of the substrate "ORVI" and $5 \%$ of biochar, $78 \% ; 20 \%$ of the substrate "ORVI" and $5 \%$ of biochar, $77 \%$. A decrease in the standard material of mini-tubers of the Charoite variety against the background of an increase in quantitative indicators does not occur when using the substrate and biochar. Evaluation of latent viral infection of meristem plants and mini-tubers grown from them was performed by ELISA (Sandwich variant) in July and February and did not reveal latent infection in any of the variants. The determination of growing parameters was carried out a month after harvesting and showed that mini-tubers in all variants had no signs of the late blight disease, rhizoctonia disease, common scab, etc.
\end{abstract}

\section{Introduction}

In recent years, in the international trade in seed potatoes, the tendency towards a significant increase in the volume of export-import supplies of batches of minitubers has become quite clear, which have practically become an independent commodity group in the world market of original seed potatoes. This, in turn, led to the need to create standardized procedures for the technological process of in vitro clonal micropropagation and production of mini-tubers, as well as the development and implementation of modern standards and serious improvement of regulatory control in the quality control system of batches of mini-tubers to be sold [1-5].

Methods for improving primary seed production and obtaining the initial seed material - mini-tubers - are receiving close attention at the International Potato Center (Peru), in Hungary, France, England, Poland, China, South Korea and other countries. In particular, the Dutch have recently begun to use greenhouses to obtain the first tuberous generation throughout the year. Such technologies are used for accelerated propagation of new and selective varieties [5-10]. Since 1989, in South Korea a technology has been adopted, according to which in a protected environment such as a winter greenhouse, four growing seasons a year are carried out using early varieties of potatoes. From a greenhouse area of 0.5 hectares, 20 million pieces of mini-tubers are harvested per year, that is, about 1000 pieces per $\mathrm{m} 2$ per one growing season. For cultivation, an organic substrate is used with the addition of vermiculite and perlite minerals. In South Korea, this number of mini-tubers is fully self-sufficient [11].

In the production of mini-tubers in a protected environment by means of thickened planting an economical use of the area is achieved, which allows for stricter phytosanitary control than in the field [12-16]. In addition, the use of small tubers as seeds allows producers to reduce the consumption of planting material per hectare by 1.5-2 times, reduces the cost of storage, sorting and transportation [5, 6, 11]. Relatively small tubers are less damaged during mechanized harvesting and processing when laying for storage, they are easier to treat with fungicides and insecticides and more accessible for manual sorting, and are similar to the original varieties in the tuber shape, skin color and texture.

The study of physiological processes of obtaining a potato crop in greenhouses, formation of the plant morphotype and crop structure under these conditions, as a stage of propagation of the initial material is of great scientific, theoretical and practical interest [3, 5, 17, 18]. In contrast to the development of agrophytocenoses in the field, where the main factor that can be regulated is the mineral nutrition of plants and partly their watering, in greenhouses it is possible to maintain optimal light, humidity and temperature conditions, depending on the

\footnotetext{
Corresponding author: stown200@mail.ru
} 
phase of plant development, to maximize their production potential.

For primary seed growing of potatoes, the multiplication coefficient of the initial material is especially important, which reflects the process allowing production of the maximum number of healthy seed tubers in a shorter time [3, 16]. Growth and development of mini-tubers can be modified by a number of exogenous compounds or growing conditions, which makes them a valuable model system $[5-7,9,10]$. In the future, the production of micro-tubers will become one of the strategies of seed production, since mini-tubers are small in size and weight, disease-free and have huge advantages in storage, transportation and mechanization $[10,11,13]$. They can be produced all year round and used as the main material for potato seed production. A large number of mini-tubers realizes the potential of biotechnology, on the basis of which it becomes possible to shorten the seed production cycle, which in potatoes is one of the longest among all crops. Taking this perspective into account, in recent years, many attempts have been made to improve the technologies for obtaining mini-tubers, including the entry into industrial production of mini-tubers as a separate type of seed production or commodity.

All known technologies for the production of minitubers are divided into two categories: substrate and substrate-free. Substrates can be natural or artificial. Growing mini-tubers in hydroponic installations is associated with high material costs, which only an economically strong farm can afford. There are only few organizations and firms involved in cultivation of seed potatoes using aeroponic installations. In Russia and abroad, many seed-growing structures continue to grow mini-tubers using traditional technology $[10,11,13,16]$. The majority of seed farms uses different variations of traditional technologies for the production of potato mini-tubers; nevertheless, attempts are being made to master and use advanced technologies. There is a need for production of devices and technology which combine substrate production of mini-tubers, which is universal and preferable due to biological characteristics of potatoes and an order of magnitude higher yield of minitubers. For an innovative technology for obtaining healthy mini-tubers, a critical moment is a reasonable choice (composition) of the required substrate and its components, in which cultivation will be carried out $[1,11,12,15]$.

The overwhelming majority of large seed-growing enterprises currently grows mini-tubers in glass or film greenhouses on natural organic-mineral substrates with extensive use of peat. This technology has the lowest cost price of a mini-tuber, no more than $\$ 0.15 /$ piece.

One can grow mini-potato tubers in pots or other containers installed in greenhouses. The fundamental difference from a field method is an increased protection against disease vectors due to protected cultivation, as well as the year-round type of cultivation.

Growth and development of mini-tubers can be altered by a number of exogenous compounds or growing conditions, which makes them a valuable model system $[10,16]$. In the future, the production of micro- tubers will become one of the strategies of seed production, since micro-tubers are small in size and weight, disease-free and have huge advantages in storage, transportation and mechanization [11]. They can be produced all year round and used as the main material for potato seed production.

A potato plant is by nature a substrate culture, and many scientists believe that obtaining a healthy source seed material should be carried out in soil substrates. Therefore, despite active dissemination of hydroponic technologies, search continues for methods of obtaining mini-potato tubers using soil substrates, ensuring the achievement of the highest possible reproduction rate by increasing each plant's productivity. Moreover, it is desirable to obtain tubers of the same size. One of the important indicators of the quality of potato seed is the weight of tubers. Many studies have found that potatoes' stem-forming ability depends on the mass of tubers planted, and the yield depends on the size of a bush, that is, on the number of stems. Therefore, it is important to obtain seeds weighing more than $1.5 \mathrm{~g}$. Typically, one crop is grown per year. In Europe it is considered normal to get 4-5 tubers from one plant. Differentiated application of micronutrient fertilizers, biologically active substances, PPR allows increasing the multiplication factor to 8-10.

In vegetable growing, there is a wealth of experience in the selection and preparation of a wide variety of substrates for a wide range of crops in greenhouses [12]. Various components are used: peat, perlite, vermiculite, mineral wool, expanded clay, and zeolites [13]. In the Republic of Belarus, artificial substrates have been developed on the basis of a mixture of artificial cation and anion exchangers (under the trade marks "Biona" and "Triona", which saturate with the necessary nutrients by the method of ion exchange) [11-13]. However, the cost of such substrates is high and amounts to 20-30 Euros $/ \mathrm{kg}$, which is an obstacle to their widespread use. The most popular growing medium mentioned in the literature is peat, various mixtures containing peat, for example, a mixture of sand and peat $1: 1$, a mixture of peat and sand $2: 1,2: 1: 1$ soil, vermiculite and sandy substrate, a mixture of peat and perlite in a $5: 1$ ratio, $1: 1$ peat - perlite, peat-clay mixture $1: 1[5-7,17,18]$.

Disposable substrates based on natural peat with addition of a mineral component and its proportion in the mixture have a real prospect for widespread use in potato growing. The most suitable organic component for the preparation of substrates is lowland aired peat. In Mexico, mixtures of organic substrates are successfully used in the production of potato mini-tubers $[5,8,9]$.

Naturally occurring peat contains 86-93\% water and only $7-14 \%$ dry matter. When harvesting, it is dried to a moisture content of 55-65\%. At the same time, it is ventilated, and compounds toxic to plants disappear from it. Peat is a good antiseptic due to the presence of phenolic compounds and organic acids. It has high absorption and buffering capacity. These two properties are the main and decisive ones when using it as a substrate or a component of a substrate mixture for growing seed potatoes. In order to obtain the optimal mechanical composition of the substrate, a series of 
experiments was carried out to select the optimal mineral component and determine the ratio of the components.

To date, a number of reviews have been published in literature on the main lines of research on the effect of biochar on soil properties and plant productivity. The addition of biochar can directly or indirectly increase potato plant productivity by improving nutrient retention and release characteristics. Certain experimental material has been accumulated on the study of the ameliorative properties of biochar. The addition of biochar to agricultural soil has been reported to reduce gas emissions, and also that biochar improves soil fertility, stimulates plant growth, increases yields and reduces pollution $[19,20]$. The use of biochar, as a rule, improves soil structure. Biochar can improve soil aggregation and increase the proportion of watertight aggregates. This can lead to increased porosity and water infiltration, as well as reduce the risk of water erosion [21-24]. However, despite the positive feedback from the scientific community on the results of the effect of biochar on soils and plants, questions about the prospects for widespread use of biochar as an ameliorant are still open, which is explained by the existence of conflicting data on its effect on soil properties [24-28].

In the Leningrad Scientific Research Institute of Agriculture "Belogorka", potato seed breeding has been carried out since the 1930 s. Potato varieties bred by the Institute have been introduced in many regions of Russia and neighboring countries.

The Charoite variety has been included in the State Register of Breeding Achievements of the Russian Federation since 2014 in seven regions of admission [29]. The variety is resistant to potato cancer (pathotype 1), common scab, rhizoctonia, ultra-early maturing. To increase the volume of the original seed potatoes of the Charoite variety, different methods of propagation of the initial material were used: through clone nurseries in the field and through vessels in protected ground. It was revealed that one plant of this variety forms 10 tubers of the standard seed fraction on average in the field, and in containers of 5 liters, from 4 to 5 pieces when using the peat substrate "Agrobalt-S" [29].

Therefore, the purpose of the study was to assess the effect of the substrate "ORVI" (Latvia) mixed with peat soil "Agrobalt-S" (Russia) and birch biochar (Russia) on the growth, development and formation of the yield of the Charoit variety.

The objects of research were meristem plants; mass and number of mini tubers; when grown on "Agrobalt C" peat fertilizer and mixed with "ORVI" biochar substrate in a closed greenhouse.

\section{Material and methods}

The studies were carried out in a protected environment. Microplants were grown in 5.5 liter vessels. The preparation of the vessels for planting consisted of filling them with peat soil with various doses of components.

Peat soil "Agrobalt-S" is made of high-moor peat with a low degree of decomposition, mined by carving or milling. Lime materials (dolomite flour, limestone flour) are used to neutralize peat. Enrichment of peat with nutrients is carried out by introducing a complex microgranular fertilizer PG MIX (Yara), which ensures uniform distribution of nutrients throughout the substrate, a high degree of their assimilation and stability of the crop. Contains a standard fraction of peat $0-20$ $\mathrm{mm} ; \mathrm{pH}_{\mathrm{KCl}}$ 5.4. Organic matter $80 \%, \mathrm{~N} 150 \mathrm{~g}$ per liter, $\mathrm{P}_{2} \mathrm{O}_{5} 150 \mathrm{~g}$ per liter, $\mathrm{K}_{2} \mathrm{O} 150 \mathrm{~g}$ per liter, Ca $120 \mathrm{~g}$ per liter, $\mathrm{Mg} \mathrm{30g}$ per liter. This peat substrate served as a control variant for growing mini-tubers of the Charoite variety.

In the second variant, $10 \%$ of the volume of the "ORVI" substrate and $5 \%$ of biochar were added to the standard peat soil; in the third, $20 \%$ of the same substrate and $5 \%$ of biochar were added. Birch charcoal is an environmentally friendly product containing about $80 \%$ of carbon.

The "ORVI" substrate produced in Latvia is an organic-mineral substance produced from organic waste, sewage sludge and peat by fermentation at a certain temperature. This product has an EU phytosanitary environmental safety data sheet. The content of organic matter in the substrate "ORVI" is $95 \%, \mathrm{pHKCl}-5.8$.

The planting mixture was thoroughly mixed. The vessels were filled and watered one day before the microplants were planted. Planting of microplants was carried out on May 26, 2020 in protected ground conditions. All three variants of the experiment had three replicates each. The total area of the experiment was 15 sq. m, 162 microplants in vessels, 54 in each variant. 18 microplants in vessels with an area of 0.09 sq. m were allocated to one plot. Plants were not fertilized during the growing season. Watering of microplants was carried out as needed, taking into account plant development, with an initial watering volume of $200 \mathrm{ml}$ of water per vessel. By the time of harvesting, the volume of irrigation increased to $500 \mathrm{ml}$ of water per plant.

During the growing season, three treatments were carried out against aphids-carriers of viruses (Tsipi KS with a consumption rate of $1.6 \mathrm{ml} / \mathrm{l}$, Sharpei - $0.16 \mathrm{~g} / \mathrm{l}$, Tsipi KS - $1.6 \mathrm{ml} / \mathrm{l}$ ) and two treatments against late blight and alternaria (Solanum - $5 \mathrm{~g} / \mathrm{l}$, Shirlan $2 \mathrm{~g} / \mathrm{l}$ ).

Determination of the fractional composition and sowing quality indicators of mini-tubers was carried out using the current standards $[1,11,14,29]$. The data on the yield and its constituent elements were processed statistically using ANOVA.

\section{Results and discussion}

The experimental study of various peat-fertilizing mixtures which improve quality indicators and increase the yield of mini-tubers in the pot method of growing microplants was carried out using the Charoite potato variety. This variety is very early to crop, and it can give a marketable crop of tubers on the 60th day after planting. When harvested in the early ripening period, it has a high percentage of marketability.

Microplants of the Charoite variety took root on the 7 th day in all variants. As the microplants grew and developed, biometric parameters were measured. In 
contrast to the Charoite potato variety obtained in the field, where the number of stems of one bush, as a rule, was more than one, in all three variants of the experiment each plant produced a single stem. The plants grew well, but did not bloom. The differences between the variants were noted in terms of the onset of the aging phases and withering away of the foliage.

The height of plants according to two measurements at different times differed between the variants (table 1). Both on the 21st day and on the 30th day after planting, they were not as tall as the control variant. Moreover, in the second variant in both cases the height was the lowest and amounted to 81 and $78 \%$ of the control, respectively. Potato tubers were harvested after the complete wilting of the foliage. The mass and number of tubers were recorded for each vessel, followed by summing it up by replicates and variants. It can be noted that the use of peat-fertilizing mixtures of different composition influenced the growth of potato microplants in the experiment.

Table 1. Height of plants in vessels at different times from planting, cm

\begin{tabular}{|c|c|c|c|c|c|}
\hline \multirow{2}{*}{ Variant } & \multicolumn{3}{|c|}{ Replicate } & \multirow{2}{*}{$\begin{array}{l}\text { Average } \\
\text { height of } \\
\text { plants }\end{array}$} & \multirow{2}{*}{$\begin{array}{l}\% \text { of the } \\
\text { reference } \\
\text { level }\end{array}$} \\
\hline & 1 & 2 & 3 & & \\
\hline \multicolumn{6}{|c|}{ Day 21} \\
\hline $\begin{array}{c}1 \\
\text { (control) }\end{array}$ & 15.3 & 15.2 & 14.9 & 15.2 & 100 \\
\hline 2 & 12.0 & 12.4 & 12.5 & 12.3 & 81 \\
\hline 3 & 13.6 & 14.7 & 12.8 & 13.7 & 90 \\
\hline \multicolumn{6}{|c|}{ Day 30} \\
\hline $\begin{array}{c}1 \\
\text { (control) }\end{array}$ & 33.1 & 32.6 & 33.8 & 33.1 & 100 \\
\hline 2 & 24.5 & 27.3 & 25.6 & 25.8 & 78 \\
\hline 3 & 29.7 & 32.3 & 31.7 & 31.2 & 94 \\
\hline
\end{tabular}

The analysis of the obtained results of using the "ORVI" substrate and biochar in addition to the "Agrobalt S" peat soil had a positive effect on the formation of the yield of minitubers. The largest number of mini-tubers was observed in the variant with $20 \%$ of the volume of the "ORVI" substrate and $5 \%$ of biochar - 6.2 pieces per bush (Table 2-3). However, there is a tendency towards a decrease in the total mass of mictubers from one bush (Table 4).

Table 2. Mini-tubers mass, grams.

\begin{tabular}{|c|c|c|c|}
\hline \multirow{2}{*}{ Variant } & \multicolumn{3}{|c|}{ Replicate } \\
\cline { 2 - 4 } & $\mathbf{1}$ & $\mathbf{2}$ & $\mathbf{3}$ \\
\hline 1 & 3145 & 2978 & 3164 \\
\hline 2 & 3228 & 3336 & 2958 \\
\hline 3 & 2821 & 2733 & 2961 \\
\hline \multicolumn{3}{|c|}{ Least significant difference $05=138.6$} \\
\hline
\end{tabular}

Table 3. Number of mini-tubers, pieces

\begin{tabular}{|c|c|c|c|}
\hline \multirow{2}{*}{ Variant } & \multicolumn{3}{|c|}{ Replicate } \\
\cline { 2 - 4 } & $\mathbf{1}$ & $\mathbf{2}$ & $\mathbf{3}$ \\
\hline 1 & 93 & 98 & 110 \\
\hline 2 & 108 & 107 & 109 \\
\hline 3 & 116 & 116 & 104 \\
\hline \multicolumn{3}{|c|}{ Least significant difference05 $=10.7$} \\
\hline
\end{tabular}

Table 4. Average yield indicators of the Charoite variety by variants

\begin{tabular}{|c|c|c|c|c|}
\hline \multicolumn{2}{|c|}{ Variant } & $\mathbf{1}$ & $\mathbf{2}$ & $\mathbf{3}$ \\
\hline \multirow{2}{*}{ Tuber mass, g } & Total & 9287 & 9552 & 8515 \\
\cline { 2 - 5 } & $\begin{array}{c}\text { From 1 } \\
\text { bush }\end{array}$ & 172 & 177 & 158 \\
\hline $\begin{array}{c}\text { Number of tubers, } \\
\text { pcs. }\end{array}$ & Total & 301 & 324 & 336 \\
\cline { 2 - 5 } & $\begin{array}{c}\text { From 1 } \\
\text { bush }\end{array}$ & 5.5 & 6.0 & 6.2 \\
\hline \multicolumn{2}{|c|}{$\%$ of the reference level } & 100 & 109 & 112 \\
\hline
\end{tabular}

As a result of the combined use of the "ORVI" substrate and biochar in addition to the peat soil, "Agrobalt S" had a positive effect on the yield of large fractions of microtubers of the Charoit variety, relative to the control (Table 5). However, there is a decrease in the average mass of tubers relative to the control variant with the use of "Agrobalt S" peat soil.

Table 5. Productivity of microtubers of the Charoite variety by fractions and variants, (2020)

\begin{tabular}{|c|c|c|c|c|c|}
\hline \multirow[t]{2}{*}{ Variant } & \multirow{2}{*}{$\begin{array}{c}\text { Fraction, } \\
\mathbf{m m}\end{array}$} & \multirow{2}{*}{$\begin{array}{c}\text { Average } \\
\text { tuber } \\
\text { weight, } g\end{array}$} & \multirow{2}{*}{$\begin{array}{l}\text { Tuber } \\
\text { mass, } g\end{array}$} & \multicolumn{2}{|c|}{$\begin{array}{c}\text { Tuber } \\
\text { mass, } \mathrm{g}\end{array}$} \\
\hline & & & & pieces & $\%$ \\
\hline \multirow{9}{*}{$\begin{array}{c}\text { 1.Peat fertilizer } \\
\text { "Agrobalt S" } \\
100 \% \\
\text { (control) }\end{array}$} & $<10$ & 1 & 1 & 3 & 1 \\
\hline & $11-20$ & 1 & 10 & 10 & 3 \\
\hline & $21-30$ & 5 & 114 & 28 & 9 \\
\hline & $31-40$ & 12 & 730 & 60 & 20 \\
\hline & $41-50$ & 24 & 1716 & 70 & 24 \\
\hline & $51-60$ & 38 & 2566 & 66 & 22 \\
\hline & $61-70$ & 56 & 2184 & 39 & 13 \\
\hline & $>71$ & 78 & 1966 & 25 & 8 \\
\hline & Total & 30 & 9287 & 301 & 100 \\
\hline \multirow{9}{*}{$\begin{array}{l}\text { 2. Peat fertilizer } \\
\text { "Agrobalt S" } \\
90 \%+5 \% \\
\text { "ORVI" substrate } \\
+5 \% \text { biochar }\end{array}$} & $<10$ & - & - & - & - \\
\hline & $11-20$ & 1 & 24 & 28 & 9 \\
\hline & $21-30$ & 4 & 146 & 31 & 9 \\
\hline & $31-40$ & 11 & 500 & 43 & 13 \\
\hline & $41-50$ & 21 & 1524 & 70 & 22 \\
\hline & $51-60$ & 35 & 2772 & 78 & 24 \\
\hline & $61-70$ & 51 & 2008 & 39 & 12 \\
\hline & $>71$ & 72 & 2548 & 35 & 11 \\
\hline & Total & 29 & 9552 & 324 & 100 \\
\hline \multirow{9}{*}{$\begin{array}{l}\text { 3. Peat fertilizer } \\
\text { "Agrobalt C" } 80 \% \\
+20 \% \text { "ORVI" } \\
\text { substrate + } 5 \% \\
\text { biochar }\end{array}$} & $<10$ & 1 & 3 & 7 & 2 \\
\hline & $11-20$ & 1 & 38 & 33 & 10 \\
\hline & $21-30$ & 3 & 120 & 32 & 10 \\
\hline & $31-40$ & 10 & 742 & 69 & 20 \\
\hline & $41-50$ & 21 & 1432 & 67 & 20 \\
\hline & $51-60$ & 34 & 1934 & 56 & 16 \\
\hline & $61-70$ & 47 & 1704 & 36 & 11 \\
\hline & $>71$ & 70 & 2542 & 36 & 11 \\
\hline & Total & 25 & 8515 & 336 & 100 \\
\hline
\end{tabular}

To find statistically significant differences in the variants of the experiment, we carried out ANOVA on the quantitative indicators of the mini-tubers of the Charoite variety. According to Fisher's criterion, there was a statistically significant difference in the number of tubers and their mass by fractions between the variants with the "ORVI" substrate (table 6). Statistically significant differences were obtained between the control variant and the variants with the substrate and biochar. 
Consequently, the use of these media is justified by the increased number of mini-tubers and their mass.

Table 6. ANOVA analysis of statistical differences by experimental variants for the indices of mini-tubers of the Charoite variety

\begin{tabular}{|c|c|c|c|c|c|c|}
\hline Variance & $\begin{array}{c}\text { Sum } \\
\text { of Squares }\end{array}$ & $\begin{array}{c}\text { Degrees } \\
\text { of Freedom }\end{array}$ & $\begin{array}{c}\text { Mean } \\
\text { Square }\end{array}$ & FF & $\begin{array}{c}\mathbf{F}_{t} \\
p=5 \%\end{array}$ & $\begin{array}{c}\text { Probability of } \\
\text { accepting the null } \\
\text { hypothesis }\end{array}$ \\
\hline \multicolumn{7}{|c|}{ by mass of tubers by variants } \\
\hline \multicolumn{7}{|c|}{ Variant \#1-2 } \\
\hline Total & 15927609 & 14 & & & & \\
\hline Variants & 14748882 & 7 & 2106983 & 12.27 & 4.22 & 0.003546 \\
\hline Repetitions & 148454.6 & 1 & & & & \\
\hline Residual & 1030272 & 6 & 171712 & & & \\
\hline \multicolumn{7}{|c|}{ Variant \#1-3 } \\
\hline Total & 14625848 & 15 & & & & \\
\hline Variants & 14104236 & 7 & 2014891 & 29.12 & 3.79 & 0.000116 \\
\hline Repetitions & 37249 & 1 & & & & \\
\hline Residual & 484363 & 7 & 69194.71 & & & \\
\hline \multicolumn{7}{|c|}{ Variant \#2-3 } \\
\hline Total & 14836706 & 14 & & & & \\
\hline Variants & 13195985 & 7 & 1885141 & 8.61 & 4.21 & 0.008996 \\
\hline Repetitions & 326902.4 & 1 & & & & \\
\hline Residual & 1313818 & 6 & 218969.7 & & & \\
\hline \multicolumn{7}{|c|}{ by mass of tubers by variants } \\
\hline \multicolumn{7}{|c|}{ Variant \#1-2 } \\
\hline Total & 7177.333 & 14 & & & & \\
\hline Variants & 6077.333 & 7 & 868.1905 & 6.36 & 4.21 & 0.01923 \\
\hline Repetitions & 280.0298 & 1 & & & & \\
\hline Residual & 819.9702 & 6 & 136.6617 & & & \\
\hline \multicolumn{7}{|c|}{ Variant \#1-3 } \\
\hline Total & 7674.438 & 15 & & & & \\
\hline Variants & 7233.938 & 7 & 1033.42 & 19.88 & 3.79 & 0.000407 \\
\hline Repetitions & 76.5625 & 1 & & & & \\
\hline Residual & 363.9375 & 7 & 51.99107 & & & \\
\hline \multicolumn{7}{|c|}{ Variant \#2-3 } \\
\hline Total & 5424 & 14 & & & & \\
\hline Variants & 4935 & 7 & 705 & 10.06 & 4.21 & 0.006005 \\
\hline Repetitions & 68.57143 & 1 & & & & \\
\hline Residual & 420.4286 & 6 & 70.07143 & & & \\
\hline
\end{tabular}

\section{Conclusion}

The yield of standard tubers $(9-60 \mathrm{~mm})$ in accordance with the applicable state standards of the Ministry of Agriculture of the Russian Federation was $78 \%$ when using "Agrobalt S" peat soil. Using $10 \%$ substrate "ORVI" and biochar 5-78\%, and $20 \%$ substrate and biochar $5 \%$ "ORVI" - $77 \%$ of standard tubers.

Therefore, in fact, there was no decrease in the standard material of mini-tubers of the Charoite variety against the background of an increase in quantitative indicators when using the substrate and biochar. Evaluation of latent infection with viruses of meristem plants and mini-tubers grown from them was performed by ELISA (Sandwich variant) in July and February and did not reveal latent infection in any of the variants.

The determination of growing parameters was carried out a month after harvesting showed that mini-tubers in all variants had no signs of late blight disease, rhizoctonia disease, common scab, etc.

\section{References}

1. Z.A. Marzoev, I.S. Kardanova, O.S Khutinaev, S.N. Zebrin, I.A. Gracheva, B.V. Anisimov, Innovative technologies for growing mini-tubers in virus-free potato seed production (Analytical review), Euras. Sci. Assoc., 8-6(66), 386-394 (2020)

2. J.S. Im, S.G. Seo, M.O. Kim, C.G. Cheon, Y.E. Park et al., Recent trend and prospects of potato industry in Kazakhstan, J. Kor. Soc. Int. Agric., 30, 177-183 (2018)

3. I. Savchenko, S. Pryamov, K. Pshechenkov, E. Simakov, V. Tulcheev et al., Industry of "second 
bread" production: ways out of the crisis, Agrar. Rev., 4, 28-38 (2014)

4. M.W. Mbiyu, J. Muthoni, J. Kabira, G. Elmar, C. Muchira et al., Use of aeroponics technique for potato (Solanum tuberosum) minitubers production in Kenya, J. of Horticult. and Forestry, 4(11), 172-177 (2012)

5. R. Tierno, A. Carrasco, E. Ritter, J.I.R. de Galarreta, Differential Growth Response and Minituber Production of Three Potato Cultivars Under Aeroponics and Greenhouse Bed Culture, Amer. J. of Potato Res., 91(4), 346-353 (2014)

6. S.C. Zimba et al., Minituber production potential of selected Potato (Solanum tuberosum L.) genotypes in different propagation media, Afric. J. of Biotechnol., 13(48), 4430-4437 (2014)

7. S.C. Zimba et al., Minituber production potential of selected Potato (Solanum tuberosum L.) genotypes in different propagation media, Afric. J. of Biotechnol., 13(48), 4430-4437 (2014)

8. G.M.A. Arellano, G.E.E. Villavicencio, G.S.J. García, Producción de plántulas y semilla prebásica de variedades comerciales de papa libres de enfermedades, Instituto Nacional de Investigaciones Forestales, Agrícolas y Pecuarias. Campo Experimental Saltillo, Folleto técnico núm, 41, 46 (2010)

9. R. Flores-López, E. Sotelo-Ruiz, O. RubioCobarrubias, A. Álvarez-González, M. MarínCasimiro, Niveles de NPK para la producción de minitubérculos de papa en invernadero en el Valle de Toluca, Rev. Mex. Cienc. Agríc., 7(5), 1131-1142 (2016)

10. S.N. Petukhov, A.G. Aksenov, A.V. Sibirev, A.S. Dorokhov, Technological and biological prerequisites for the development of innovative technology for potato mini-tubers production, Agrotech. and energy supply, 3, 24 (2019)

11. S. Banadysev, Potato mini-tubers production technologies: what to prefer? Agrar. Rev., 6(34), 20-21 (2012)

12. T. Yanchevskaya, Promising technology for optimization of primary seed production of potatoes, Sci. and Innovat., 8(42), 1-2 (2006)

13. M.K. Koksharova, Mini-tubers - a valuable planting material in primary seed-growing, Achiev. of sci. and technol. of the agro-indust. complex, 06, 46-48 (2011)

14. Pest free potato (Solanum spp.) microprogative material and minitubers for international trade International standards for phitosanitary measures (ISPM, FAO, 2011), 20 p.

15. I. Dimante, Z. Gaile, Potato minitubers technology its development and diversity, Res. for Rural Devel., 1, 69-76 (2014)

16. A. Gābere, Influence of various growing factors on recovered potato cultivars meristem plant yield in greenhouse, Agronomijas Vēstis, 6, 28-33 (2004)
17. A.J.H. Veeken, W.J.M. Lommen, How planting density affects number and yield of potato minitubersin a commercial glasshouse production system, Potato Res., 52(2), 105-119 (2009)

18. H. Vanaei, D. Kahrizi, M. Chaichi, G. Shabani, K. Zarafshani, Effect of genotype, substrate combination and pot size on minituber yield in potato (Solanum tuberosum L.), Amer.-Euras. J. of Agricult. and Envir. Sci., 3(6), 818-821 (2008)

19. L. Beesley, E. Moreno-Jimenez, J.L. Gomez-Eyles, E. Harris, B. Robinson, T. Sizmur, A review of biochars \& potential role in the remediation, revegetation and restoration of contaminated soils, Envir. Pollut., 159, 3269-3282 (2011)

20. C.J. Barrow, Biochar: Potential for countering land degradation and for improving agriculture, Appl. Geogr., 34, 21-28 (2012)

21. S. Brodowski, B. John, H. Fless, W. Amelun, Aggrcgatc occltided black carbon in soil. Europ. J. Soil Sei., 57(4), 539-546 (2006)

22. Y. Yanai, K. Toyota, M. Okazaki, Effects of charcoal addition on $\mathrm{NO}$ emissions from soil resulting from rewetting air-dried soil in short-term laboratory experiments, Soil Sei. Plant Nutr., 53, 181-188 (2007)

23. J. Lehman, S. Joseph, Biochar for environmental management science, technology and implementation (International Ltd, Padstow, Cotnwall, 2015), 928 p.

24. E.Ya. Rizhia, N.P. Buchkina, I.M. Mukhina, C.B. Pavlik, E.B. Balashov, Application of biochar in agriculture of the Russian Federation: Methodological recommendations (AFI, St. Petersburg, 2014), 28 p.

25. N. Hennouni, K. Madi, F. Taibi, T. Kestali, S. Etsouri, M. Boudelaa, Influence of several substrates on growth parameters and yield of potato minitubers (Solanum tuberusum), Advan. in Envir. Biol., 10(7), 90-98 (2016)

26. Y. Ding, Y. Liu, S. Liu, Z. Li, X. Tan et al., Biochar to improve soil fertility, A rev. Agron. Sust. Dev., 36(2), 36 (2016)

27. Z.M. Dai, X.J. Zhang, C. Tang, N. Muhammad et al., Potential role of biochars in decreasing soil acidification: a critical review, Sci. Total Envir., 581-582, 601-611 (2017)

28. A. El-Naggar, S.S. Lee, J. Rinklebe, M. Farooq, H. Song et al., Biochar application to low fertility soils: A review of current status, and future prospects, Geoderma, 337, 536-554 (2019)

29. T. Shelabina, D. Danilov, A. Rodionenkov, A. Kuznetsov, Influence of Growing Medium on the Parameters and Yield Capacity of the Mini Tuber Potato of the Charoite Variety, KnE Life Sci., 6(3), 584-592 (2021) 